\title{
АНТИОКСИДАНТНАЯ АКТИВНОСТЬ НОВЫХ ФУНКЦИОНАЛЬНО ЗАМЕЩЁННЫХ 1Н-ИНДЕН-1,3(2Н)-ДИОНА И ИНДЕНОБЕНЗОФУРАНА
}

\author{
А.Д. Осипова', В.П. Осипова², М.А. Половинкина², \\ А.В. Великородов ${ }^{3}$, Н.Т. Берберова' \\ ${ }^{1}$ Астраханский государственный технический университет, \\ 414056, Россия, г. Астрахань, ул. Татищева д.16. \\ Федеральный исследовательский центр ЮНЦ РАН, \\ 344006, Россия, г. Ростов-на-Дону, просп. Чехова, д. 41. \\ 3 1Астраханский государственный университет, \\ 414056, Россия, г. Астрахань, ул. Татищева д.20.
}

DOI: 10.19163/MedChemRussia2021-2021-282

E-mail: osipova_nd95@mail.ru

В работе изучены восстановительные свойства новых функционально замещенных 1 -инден-1,3(2H)-диона $(1,2)$ и инденобензофурана $(3,4)$, полученных конденсацией нингидрина с 2,6-ди-трет-бутилфенолом, метил $N$-фенилкарбаматом, 2,4-ди-третбутилфенолом и 2-(1-адамантил)-4-метилфенолом. Несмотря на наличие систем переноса атомов водорода (HAT-механизм), функционально замещенные соединения 1-4 не прояв-

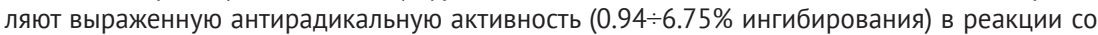
стабильным 1,1-дифенил-2-пикрилгидразильным радикалом (ДФПГ-тест).

\begin{tabular}{|c|c|c|c|c|}
\hline & 1 & 2 & 3 & 4 \\
\hline ДФПГ, \% & $5.22 \pm 0.03$ & неактивно & $0.94 \pm 0.01$ & $6.75 \pm 0.05$ \\
\hline TEACCUPRAC & $0.48 \pm 0.01$ & $0.11 \pm 0.02$ & $0.29 \pm 0.05$ & $0.24 \pm 0.03$ \\
\hline $\begin{array}{l}\text { Fe2+ -хелат. } \\
\text { актив., \% }\end{array}$ & $40.1 \pm 0.1$ & $33.6 \pm 0.5$ & $38.4 \pm 0.2$ & - \\
\hline TEACFRAP & $0.44 \pm 0.05$ & $0.34 \pm 0.03$ & $0.28 \pm 0.02$ & $0.18 \pm 0.01$ \\
\hline
\end{tabular}

Восстановительная способность изучена в CUPRAC и FRAP-тестах, основанных на способности соединений 1-4 переносить электроны на $\mathrm{Cu}^{2+}$ и $\mathrm{Fe}^{3+}$, соответственно. В отличие от ДФПГ-теста, данные методы позволяют выявить антиоксиданты, которые являются только донорами электронов, а не атомов водорода. Активность выражена в эквивалентах стандарта - тролокса (TEAC FRAP $=1$ и TEAC CUPRAC $_{\text {- }}$ ). Установлена значительно меньшая восстановительная активность соединений $1-4(0.11 \div 0.48)$ по сравнению с эталоном. По способности связывать ионы $\mathrm{Fe}^{2+}$ оценены металлхелатирующие свойства функционально замещенных $1 H$-инден-1,3(2H)-диона и инденобензофурана. Полученные данные также свидетельствуют об умеренной $\mathrm{Fe}^{2+}$-хелатирующей активности соединений 1-4 (33.6 $\left.\div 40.1 \%\right)$. Суммарно большую антиоксидантную активность проявляет соединение 1, что объясняется наличием в структуре двух антирадикальных 2,6-ди-трет-бутилфенольных фрагмента.

Работа выполнена при поддержке гранта РФФИ № 19-03-00006.

$$
-282-
$$

